\title{
STRATEGIC FRAMEWORK FOR INTRODUCTION OF ISLAMIC \\ BANKING IN INDIA
}

\section{SANA BEG}

Assistant Professor, Department of Management, School of Management and

Business Studies, Jamia Hamdard, New Delhi, India

\begin{tabular}{|l|}
\hline ABSTRACT \\
India has a very robust conventional banking system. However, lack of availability of Islamic-Banking in India \\
results in huge losses of investments from rich Gulf nations that are looking for Shariah-Compliant investment avenues. \\
Besides, India has the second highest Muslim population in the world. They too have been demanding Islamic-Banking \\
in India. India would stand to gain a lot if Islamic Banking is gradually introduced. Many high-level committees of the \\
Government as well as the Reserve Bank of India have advocated for Islamic Banking. This paper is an attempt to \\
suggest a framework for the Introduction of Islamic Banking in India. \\
KEYWORDS: Banking Act, Government, Islamic banking, India, Reserve Bank of India \& Strategic Framework
\end{tabular}

Received: Jul 08 2017; Accepted: Jul 24 2017; Published: Jul 27 2017; Paper Id.: IJECRAUG20179

\section{INTRODUCTION}

Banks are commercial establishments, but have some unique characteristics that demand the extra care and the need for appropriate supervision of government institutions like the central banks because their instability would affect their large client base and hence the entire economy of the country could be adversely affected. Thus the central banks has to ensure proper conduct and stability of the banks. The survival of the banks is because of the trust that clients have on them. A lack of trust will cease the bank to do business.

The basic function of banks is to operate both as a debtor and a creditor, and thus gains profit from the difference of the interests therein. However, a disturbance in the balance between the assets and the liabilities of the bank affects the liability and this leads to instability.

The goals of supervision and control of the banks are generally different in different countries, but there are few common goals between them:

- To ensure the financial soundness of the banks

- To ensure that the banks protect the interest of the depositors

- To ensure that the banks have good management structure

For a robust banking system in any economy, the essentials that are to be met are as follows:

- $\quad$ Sound banking structure

- Effective regulation system 
- Independent and effective supervision system

- $\quad$ Efficient and competitive industry

- Adequate supporting infrastructures

- Customer protection

\section{INTRODUCING ISLAMIC BANKING IN INDIA}

The Modern Islamic Banking emerged in Egypt a little over half a century ago, but has now spread to almost all corners of the world. It has been increasingly gaining recognition and spreading at a growth rate that is almost three times the growth rate of conventional banking. Islamic banking has gained special attention from the academicians as well as the practitioners after the global financial crisis of the last decade. It has now established its presence in over hundred countries, although enjoys a different status in different countries. It has become systemically important, especially in Asia and the Middle East. The Islamic banking segment has also penetrated in many International Monetary Fund (IMF) member countries. However, it is no more concentrated to the Asian continent and lately it is spreading fast, even in Europe and the USA, with London becoming an important center of Islamic banking and finance in the western world. Countries like Japan and China have also embraced Islamic finance.

Many countries have introduced Islamic banking parallel to the existing conventional banking. However, to be noted is that there is no fixed or right way of introduction of Islamic banking. The circumstances and macroeconomic environment differ among nations and accordingly nations took different ways of introduction of Islamic banks. India, fortunately, has a very strong and robust conventional banking structure and the legal and regulatory structures are welldeveloped. A little amendment is needed in the Banking Act to accommodate Islamic Banking. The nations need to address many issues that may arise from time to time during development and before the Islamic banking industry matures.

\section{Islamic Banking May Be Introduced in India with the Following Goals in Mind}

- Creation of competitive and efficient Islamic banking system

- Full compliance of shariah principles in the Islamic banking operations.

- Implementation of prudential principles in Islamic Banking operations.

- Systemic stability and benefits for the society.

To achieve the above mentioned goals, Islamic banks need to fulfill both the Shariah, or divine laws and the positive or man-made laws to design and deliver differentiated products and services.

In India, a systematic and gradual introduction of Islamic Banking products and services is recommended. Broadly, there would be two phases; in the first phase, we need to do the groundwork and lay the foundation of a strong Islamic banking and financial system and finalize the legal, regulatory and supervisory requirements for its smooth introduction. In the second phase, we start with the introduction of Islamic banking products in a gradual and systematic manner. 


\begin{tabular}{|c|c|}
\hline \multicolumn{1}{|c|}{\begin{tabular}{c} 
PHASE I \\
\hline $\begin{array}{l}\text { Preliminaries before Introduction of } \\
\text { Islamic Banking }\end{array}$
\end{tabular}} & $\begin{array}{c}\text { PHASE II } \\
\text { Stage-wise introduction of } \\
\text { Islamic Banking }\end{array}$ \\
\hline$\bullet \quad \begin{array}{l}\text { Modify existing legal, regulatory and } \\
\text { supervisory framework to accommodate } \\
\text { Islamic Banking. }\end{array}$ & $\bullet \begin{array}{l}\text { International Islamic Banking standards } \\
\text { manner. }\end{array}$ \\
\hline should be adhered to.
\end{tabular}

Figure 1

\section{PRELIMINARIES BEFORE INTRODUCING ISLAMIC BANKING IN INDIA}

Islamic banking is increasingly gaining more acceptance globally. In India too, there is an increasing demand from the Muslim population and also from the Muslim investors outside India to invest in developing countries in Shariahcompliant products to get higher returns. More and more countries are opening up and now Indian conventional banks are increasingly becoming interested in entering this niche market. Although as of now, the financial institutions as well as supervisory and regulatory authorities may not be entirely familiar with the range of principles governing Islamic banking. There are many other principles besides the prohibition of interest that must be observed by practitioners and supervisors in order to comply with Islamic jurisprudence. The practitioners need to understand these principles in order to serve their customers better and the supervisors and regulators need to understand any challenge that may arise because of the introduction of these new products and services.

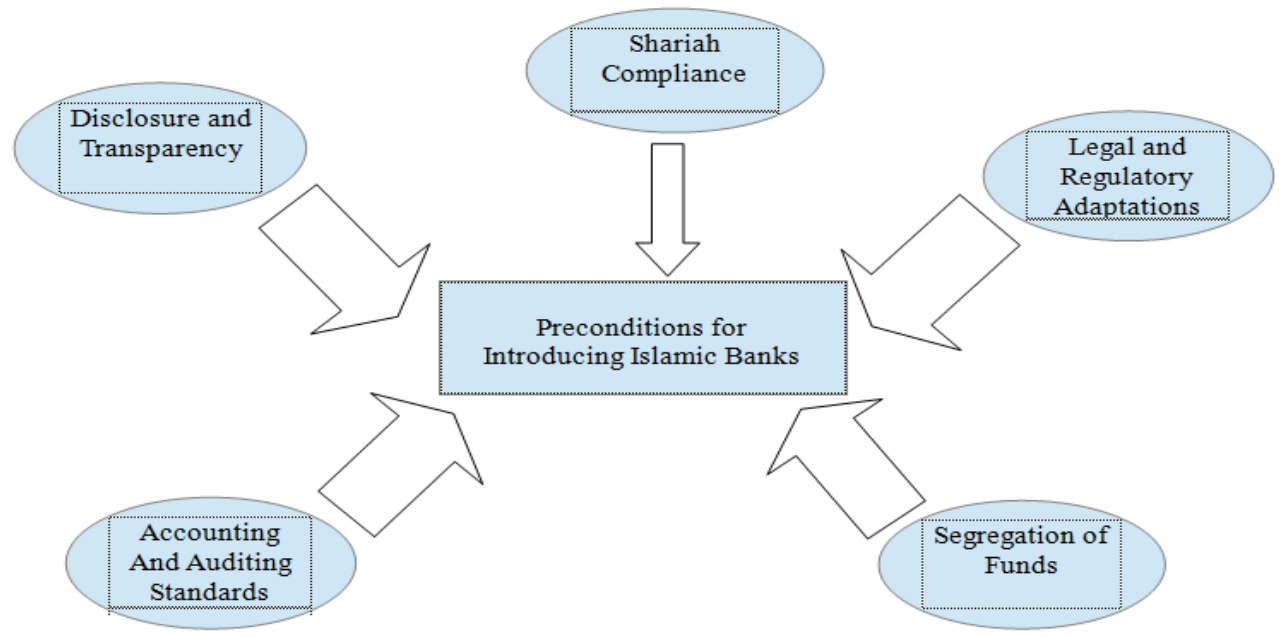

Figure 2: Preliminaries before Introducing Islamic Banking

In Islamic banking to be successfully introduced, there are some preconditions that must be met.

\section{Shariah Compliance}

As discussed earlier, Islamic banking is based on the Shariah law that is derived from the Quran and the teachings of the Prophet Mohammad (saw). Their interpretation and application is sometimes challenging and need Shariah 
expertise. The common practice globally adopted is that either all Islamic banks have their own board of Shariah scholars or in some countries different Islamic banks often share the same scholars, because of lack of expertise. The benefit of having same scholars on different boards is that lead to greater consistency across the services and products offered by these institutions. However, the drawback is that it sometimes gives rise to potential conflicts of interest, confidentiality concerns, as well as raise issues of intellectual property rights for scholars.

Thus, an institution wishing to offer Islamic products must begin by appointing a Shariah board or at least a Shariah counselor. The regulators too need to appoint Shariah experts separately to oversee and advise on the instruments and services offered by the institutions in their jurisdiction. These experts would ensure that the regulations issued by the supervisor with regard to Islamic institutions, as well as the licensing of different activities, are compatible with Islamic principles. The regulator also needs to ensure that its rulings and decisions are consistent with those of the Shariah boards of foreign supervisory agencies. Two multilateral institutions were established towards achieving greater consistency across borders - the Accounting and Auditing Organization for Islamic Financial Institutions (AAOIFI) and the Islamic Financial Services Board (IFSB). The Accounting and Auditing Organization for Islamic Financial Institutions (AAOIFI) issues internationally, recognized Shariah standards on accounting, auditing, and governance issues, while the Islamic Financial Services Board (IFSB) issues standards for the effective supervision and regulation of Islamic financial institutions. In addition, the Islamic Fiqh Academy in Jeddah commands respect of Muslim scholars and its rulings and opinions on economic and financial matters is certainly taken into consideration by Islamic finance practitioners and policy-makers.

\section{Legal and Regulatory Adaptations}

This is one of the critical issues that deals with introducing Islamic banking in the existing judicial framework along with conventional banking. Thus, there are two aspects, the legal as well as the regulatory, regarding introducing Islamic banking. The legal issue deals with the possibility of introducing Islamic banking that requires financial transactions to be governed by Shariah principles within the existing laws of the secular jurisdiction. The regulatory issue deals with the special requirements of supervision and regulation that Islamic financial institutions need.

Although the legislation does not include all Shariah principles, but mostly in these jurisdictions, the legal set-up is flexible to allow Islamic contracts. The parties involved needs to ensure that the principles are adhered to are upheld in the jurisdictions where the contract is enforced. More critical is to analyze the need for modifications in the current regulatory framework to ensure that the supervisory authorities can continue to fulfill the goals of prudential supervision of Islamic banks. In some countries, as in the United Kingdom, the same regulatory authority brings in few changes in regulations to accommodate Islamic banking while in other countries, like Bahrain, authorities issue separate regulations for conventional and Islamic banking.

The IFSB has issued guidelines on Governance, Risk Management and Capital Adequacy ratio to achieve its objectives of promotion and adoption of best practice in the regulation and supervision of Islamic financial institutions.

\section{Segregation of Funds}

To maintain the moral purity of all transactions, the funds intended for Islamic investments should remain segregated from those of non-Islamic investments. The rationale behind this is to ensure that Islamic funds do not get mixed with funds that may possibly be involved with riba, gharar or other prohibited haram activities, which otherwise 
would fail the objective of Islamic finance. Thus the banks are required to establish separate capital funds, accounts and reporting systems.

\section{Accounting and Auditing Standards}

The Accounting and Auditing Organization for Islamic Financial Institutions (AAOIFI) was created in 1990 with the primary objective of designing and establishing a uniform accounting and auditing standards for all Islamic institutions globally. Another important role is pursuing the harmonization of Shariah-based rulings across jurisdictions to enhance and encourage more cross-border use of Islamic products and increase the growth of the Islamic banking industry. If India wishes to introduce Islamic banking, its regulators and financial institutions need to familiarize themselves with the standard set by the AAOIFI. The international consistency eases the tasks of supervisors and favor the regulated institutions, as Islamic transactions are better understood and become more attractive to investors across the globe. This would foster the integration of Islamic institutions in the international financial community.

\section{Disclosure and Transparency}

For Islamic banking to succeed in the conventional environment, it is essential that Islamic banking is perceived as a transparent and well- regulated activity and the potential depositors and investors are well-informed about the opportunities and risks. The regulators need to communicate to the public what types of Islamic institutions and products

will be supervised. Regulators should also require institutions offering Islamic products to actively pursue awareness campaigns and to ascribe to high disclosure and transparency standards.

\section{STAGES IN THE INTRODUCTION OF ISLAMIC BANKS}

As Islamic banking developments in a country, it is expected to pass through few main stages. However, all countries need not go through the same stages, or may witness elements of different stages developing simultaneously. In a country like India, three stages are proposed.

The three broad stages proposed area; an initial stage where selected Islamic products would be offered through Islamic windows and Islamic Investment banking; a second stage where full-fledged Islamic banks would be allowed to operate; and a third stage where non-bank Islamic financial institutions develop and expand the range of Islamic financial products available.

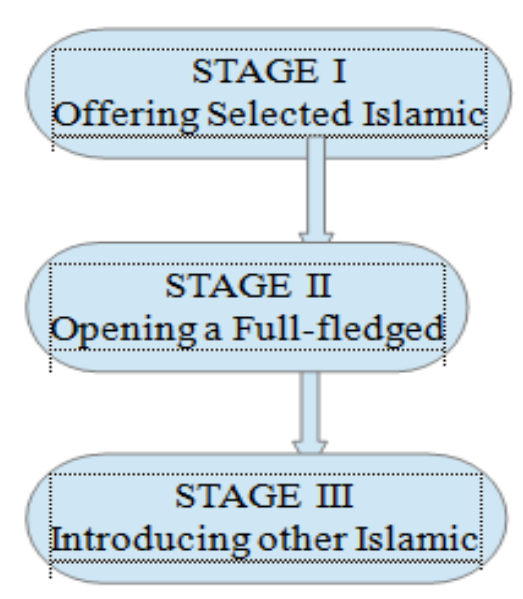

Figure 3: Stages of Introduction of Islamic Banking in India 


\section{Stage I: Offering Selected Islamic Financial Products}

Setting up Islamic Windows: In response to increasing demand for Islamic financial products resulting from a growing Muslim population and growing pool of international investors, large number of commercial banks around the world are considering the possibility of offering Shariah-compliant products. India too needs to take advantage of this opportunity. To begin, ideally with a commercial bank can open a so-called Islamic window using the existing branch network to reach to the potential new clientele. The Islamic window is a part of the conventional bank that undertakes shariah-compliant financial intermediation. It does not have a separate legal existence. This, generally, has been the strategy of countries having a Muslim minority population.

A conventional bank can open an Islamic window through which customers can conduct business utilizing only Shariah-compliant products. The bank has to ensure that co-mingling of funds do not take place. Ideally, at the beginning, the products typically offered are safekeeping deposits on the liability side of the bank and Islamic trade-finance products for small and medium companies on the asset side of the bank (Iqbal and Mirakhor, 2007). India, too, may adopt this to begin with. Banks should carefully ascertain the profitability of the Islamic windows, taking into consideration the overheads, before considering the conversion of Islamic windows into separate subsidiary.

\section{Stage II: Opening a Full-Fledged Islamic Bank}

Once an Islamic window has successfully operated for a substantial time and gathered a significant customer base that is an indicator of customer confidence and satisfaction, it may be decided to establish an Islamic subsidiary or even fully convert into an Islamic bank. Alternatively, permission may be granted to new units to work as independent banks to operate completely according to Shariah laws. A full-fledged banks are able to offer a wider range of Shariah-compliant banking products than through the Islamic window alone, such as underwriting sukuk issuances or managing Shariahcompliant investment and hedge funds, or to manage its own treasury and money market operations. In India, opening a subsidiary has the advantage that the parent company may continue servicing its conventional customers and simultaneously the subsidiary expands its Islamic activities. However, this is also true that a full-fledged Islamic banks enjoys more credibility among Muslim customers. Once full-fledged banks come into existence, it increases the supervisory burden of the regulators. The supervisors need to be familiar with the application of the IFSB standards, in addition to the Basel I, Basel II and Basel III Capital Accords.

\section{Stage III: Introducing other Islamic Financial Institutions and Instruments}

Once the Islamic banks gains ground and there is substantial reasons to believe that there is a large customer base interested in Islamic financial products, then other institutions and products may be introduced in the market. Pattern of the introduction and growth of these institutions may be adapted from other countries like Malaysia that have successfully implemented the introduction of Islamic banking in the country.

Islamic finance is also penetrating conventional systems via investment banking activities. Indeed, in an increasing number of Western countries, conventional banks are offering products specifically designed to attract Shariahcompliant investors. Islamic instruments like variants of sukuk have gained tremendous popularity and India too may exploit this opportunity where lenders specially from the Gulf Cooperation Council wishes to invest for a better return in countries other than their own provided they are complying with Islamic jurisprudence. These products will flourish in India too, because of well-developed conventional financial system. Islamic investment banking benefits from today's high 
cross-border capital mobility. The Islamic financial industry is growing and many new products are being introduced continuously. Broadly speaking, three popular areas where ample business opportunity exists are Takaful, investment funds and sukuk, and derivative instruments.

\section{ENABLING ENVIRONMENT FOR A SUSTAINABLE ISLAMIC BANKING AND FINANCIAL SYSTEM}

India has a very robust and well-developed banking system, one of the best in the world. A little amendment to the banking regulations is all that is needed to start with the Islamic Banking. After the Islamic banking has been introduced and is in place, there should be ongoing and a continuous effort from all stakeholders to provide an enabling environment for sustainability of a comprehensive Islamic banking and financial system. There should be continuous effort to improve and provide a strong, stable and robust Islamic banking and financial system.

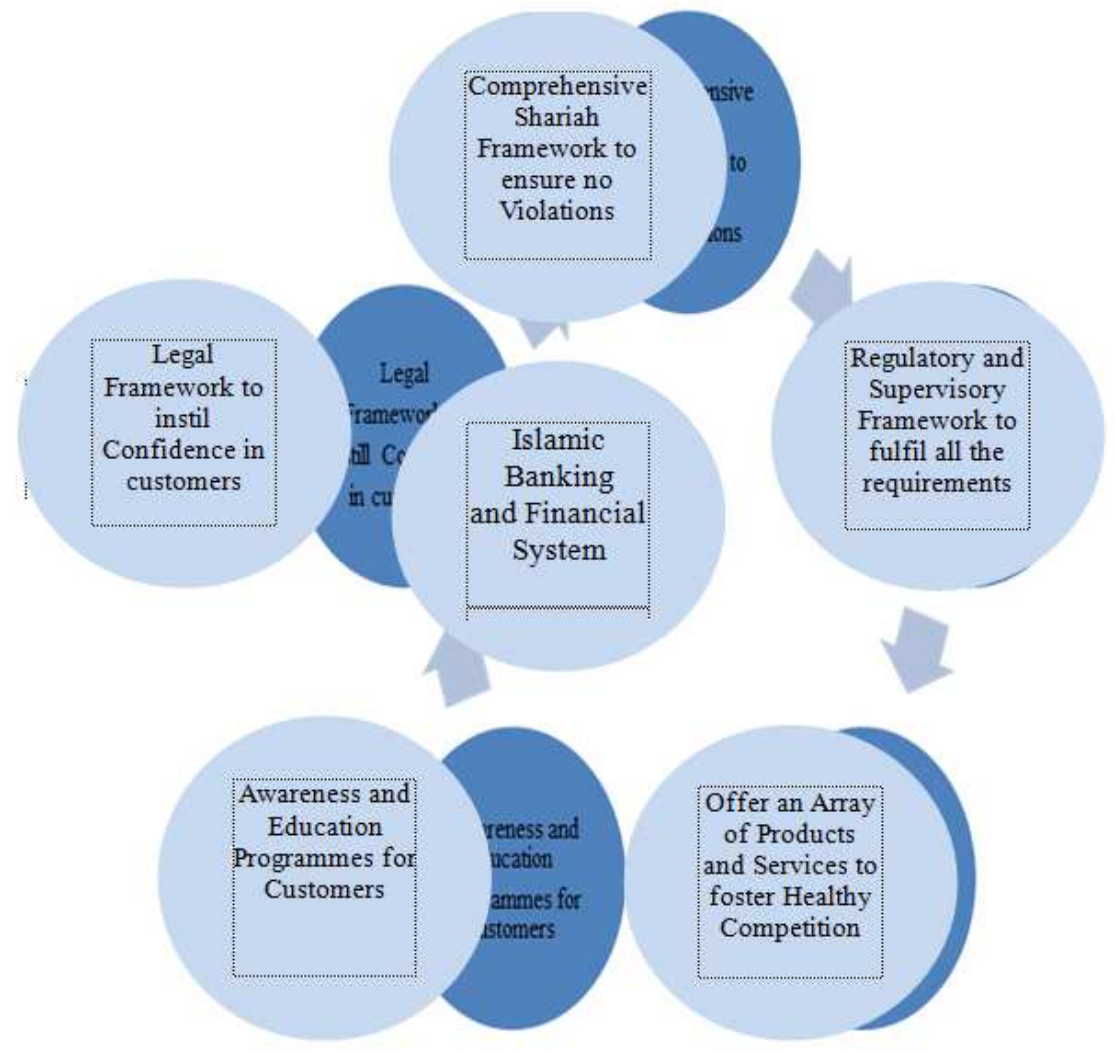

Figure 4: Sustainable Islamic Banking and Financial System

\section{CONCLUSIONS}

Many countries in the West as well as in South-East Asia have successfully introduced Islamic-Banking in their countries. India may take inspiration from countries like Malaysia, Indonesia, Bahrain etc. that can be seen as an excellent example for phase-wise introduction of Islamic banking. India fortunately has a very well-developed banking structure and the regulations in place are among the best in the world. Currently the banking structure is based on interest and Islamic banking demands an interest-free banking. A little modification in the regulations is thus desired for accommodation of 
Islamic banking. It may sound difficult but is not impossible as stressed in the Report of Financial Sector Reforms of 2009, chaired by Dr. Raghuram Rajan. Besides, to improve the financial inclusion and for poverty alleviation, special considerations and amendments are made by the RBI from time to time for NGOs, MSME lending, NBFCs etc. Similarly, another amendment can be brought for opening Islamic banking in India. Thus, it is high time that the RBI brings in the much awaited amendment to its Banking Act to include interest-free and hence Islamic banking. The Raghuram Rajan Committee report strongly suggested that India should open its door to Islamic banking in order not to keep a large section of its population deprived from banking. In December 2015, another committee of RBI for medium-term path financial inclusion has advocated in one of its recommendations about introduction of interest-free banking. And the very latest, Islamic Banking received a shot in the arm when the RBI in its annual report submitted to the Government at the Centre for the year ending $30^{\text {th }}$ June 2016, has recommended starting the interest-free banking in India.

It is suggested that India introduces an Islamic banking in a phased manner. Obviously, the first step would be to prepare grounds for it by providing adequate regulatory, supervisory, legal and sharia-compliance framework. The practitioners and the customers should be educated about Islamic banking. In the first stage of introduction of Islamic banking, India should allow Islamic windows within the conventional banks to operate that would offer shariah- compliant services and products. Once that succeeds and initial hiccups are over, full-fledged Islamic banks or Islamic subsidiaries of conventional banks can be allowed. This would result in greater reach of these banks and more products to be offered. In the third and final stage, other Islamic financial services like Takaful, sukuk and derivative instruments be brought in.

There should be an ongoing and a continuous effort from all stakeholders to improve and provide a suitable environment for the Islamic banking and financial system to exist and prosper in India. India should no longer delay the introduction of Islamic banking and begin the process of its introduction as soon as possible. It is high-time that India adopts a dual financial system where both conventional and Islamic financial systems exist and excel together.

\section{REFERENCES}

1. “A Hundred Small Steps”, Report of Committee on Financial Sector Reforms, Planning Commission, Government of India, 2008.

2. Beg, S., "Prospects, Problems and Potential of Islamic Banking In India”, International Journal of Accounting and Financial Management Research, Vol. 6, Issue 3, October 2016.

3. Beg, S., Mullick, N. H., "Increasing Financial Inclusion Through Islamic Banking in India”, International Journal of Business Management and Research, Vol. 6, Issue 1, February 2016.

4. Chapra, M. U., Khan, T., "Regulation and Supervision of Islamic Banks”, IRTI, Saudi Arabia, 2000.

5. El-Hawary D., Grais W., Iqbal Z., "Regulating Islamic Financial Institutions: The Nature of the Regulated”, World Bank Policy Research Working Paper, No. 3227, World Bank, Washington, DC, March 2004.

6. Errico L., Farahbaksh M., "Islamic Banking: Issues in Prudential Regulations and Supervision”, IMF Working Paper, WP/ 98/ 30, International Monetary Fund, March 1998.

7. Hassan, M. K., Lewis M. K., “Handbook of Islamic Banking”, Edward Elgar Publishing, 2007.

8. Iqbal Z., Mirakhor A., "An Introduction to Islamic Finance: Theory and Practice”, John Wiley, 2011.

9. Mejia A. L., Aljabrin S., Awad R., Norat M., Song I, "Regulation and Supervision of Islamic Banks", IMF Working Paper, WP/14/219, International Monetary Fund, December 2014. 
10. Report of the “Committee on Medium-term Path on Financial Inclusion”, Reserve Bank of India, December 2015.

11. Rosly S. A., "Critical Issues on Islamic Banking and Financial Markets: Islamic Economy, Banking and Finance, Investments, Takaful and Financial Planning”, AuthorHouse UK, 2005.

12. Sole J., "Introducing Islamic Banks into Conventional Banking System", IMF Working Paper, WP/ 07/ 157, International Monetary Fund, July 2007.

13. Song I., Oosthuizen C., "Islamic Banking Regulation and Supervision: Survey Results and Challenges", IMF Working Paper, WP/ 14/220, International Monetary Fund December 2014.

14. www.siddiqui.com/mns/ 
